\title{
Japán első színésznőképzője
}

\author{
Doma Petra
}

PhD-jelölt, Pécsi Tudományegyetem

\begin{abstract}
Az 1868-as Meiji-megújulás követöen a nyugati kultúra beáramlásával a modern, nyugati értelemben vett naturalista dráma is megérkezett Japánba, s kihivás elé állitotta a hagyományos színházi müfajokat. A radikális reformtervezetek mellett felmerült az igény a nök szinpadon való megjelenésére is, mely 1629 óta tiltva volt az országban. Az új, modern színházat meghonositani vagy épp csak a kabukit megreformálni kivánó müfajok, igy a shinpa és a shingeki is már alkalmaztak szinésznöket elöadásaikban. Felmerül azonban a kérdés, hogy honnan érkeztek ezek a szinésznök, s milyen szinpadi oktatásban részesültek. Kawakami Sadayakko, akit Japán első szinésznőjeként tartanak számon, és a 19-20. század fordulóján férje, Kawakami Otojirō társulatában amerikai és európai turnékon vett részt, a Franciaországban látott szinészakadémiák mintájára 1908-ban létrehozta a Teikoku Joyū Yōseijot, vagyis a Birodalmi Szinésznöképzö Intézményt, ahol kizárólag fiatal lányokat oktattak a szinpadi megjelenésre.
\end{abstract}

Kulcsszavak: japán szinház, szinésznö, Sadayakko, szinésznőképző, oktatás

\section{Bevezetés}

Az 1868-as Meiji-megújulást ${ }^{1}$ követően Japán alapjaiban változott meg. A sógunátus bukásával újra a császár kezébe került a tényleges hatalom, aki sok más intézkedése mellett a nyugati hatalmakhoz való felzárkózás érdekében a modernizáció útjára vezette az országot. E célt elérendő Japán nagyon rövid idő alatt különböző nyugati modelleket vett át és honosított meg a politikában, a társadalomban, az oktatásban és a gazdaságban egyaránt. A változáshoz szorosan kapcsolódott a határok és a japán piac megnyitása a külföldi kereskedelem és áruk előtt. Így a nyugati kultúra, irodalom, művészet és divat Japánba való beáramlása robbanásszerü hatást váltott ki azokban, akik kapcsolatba kerültek e kultúrával és mindent „imádtak”, ami nyugati és az újdonság erejével hatott - ez, főként a korai időszakban, elsősorban a városi lakosságot jelentette. Emellett ugyanilyen módon „ömlött

\footnotetext{
${ }^{1}$ A Meiji ishin 明治維新 megfelelőjeként Takó nyomán nem a részben félrevezető, illetve européer konnotációkat idéző „Meiji-restauráció” vagy „Meiji-forradalom” összetételeket, hanem a "Meiji-megújulás” szókapcsolatot használom. Ld. Takó, 2018.
}

ki” az országból a japán kultúra és árasztotta el a nyugatot, növelve ezzel az emberek egzotikum, és általában „a Kelet” iránti lelkesedését. „Különösen a 19-20. század fordulóján a Nyugaton eluralkodó általános válsághangulat új távlatok nyitására, új világkép kialakítására irányuló lázas keresést eredményezett, amely szükségképpen magával hozta az »egzotikus «, »romlatlan « civilizációk felfedezését, s új ihletforrásokként történő felhasználását" (Janó, 2009. 149. o.). Európában ez a fajta „keleti láz” nem várt méreteket öltött, $\mathrm{s}$ a mai napig talán legismertebb irányzata a japonisme ${ }^{2}$, mely áthatotta a festészetet és az iparművészetet egyaránt. Megnőtt a kereslet többek között a japán fametszetek, lakk- és porcelánművészeti tárgyak, illetve az irodalmi alkotások iránt is. A japán versek, főként a haikuk mellett - melyek hatással voltak például olyan korabeli költőkre és írókra, mint Whitman, Fenollosa, Kipling vagy itthon Kosztolányi - hamar elterjedtek a japán regéken vagy történelmi eseményeken alapu-

\footnotetext{
${ }^{2}$ A művészetek japán hatású egzotikus megújulásának divatja. A kifejezést Philippe Burty francia műkritikus használta először 1872-ben.
} 
ló regények, amelyek „a ködös miszticizmus légkörének megteremtésével romantikusan torzított képet rajzolnak az országról" (Janó, 2009. 161. o.). Mégis, az egyik legjelentősebb áramlatot a festészetben lehetett megfigyelni. Félix Bracquemond impresszionista festő 1856-ban ukiyo-e3 fametszeteket „fedezett fel" Auguste Delâtre nyomdász tulajdonában. Ezzel a japán fametszetek megkezdték hódító útjukat, s az 1867-es párizsi világkiállításon az egyik fó attrakciónak számítottak. Az ukiyo-e nagy hatással volt az impresszionista festészetre, sőt, számos korabeli művész Manet, Monet, Degas, Van Gogh, Gauguin - a japánokat tartotta az első impresszionistáknak, s Manet és Monet is tanulmányozta Hokusai műveit. Ennek következtében a japán művészetet a XIX. században elsősorban a fametszetek alapján ítélték meg, ami pedig számunkra még fontosabb: a képeken látottak alapján alakították ki elképzelésüket magáról Japánról, így az ország színházi világáról is (Itō, Maeda és Miyagawa, 1980. 216. o.). A japonizmus hódítása azonban nem csak a művészeteket hatotta át ily mértékben, hanem leszivárgott a hétköznapi emberek életébe is, akik különböző keleti csecsebecsékkel, legyezőkkel, bútorokkal, vázákkal, lakk tárgyakkal díszítették otthonukat, s ez az egzotikum iránti éhség vezetett oda, hogy lelkesen üdvözöltek minden egyes társulatot, színházi vagy táncos együttest, érkeztek ezek akár a „közeli”, akár a „távoli” Keletről.

A megújuláshozkötődő gyors nyugatiasodás és modernizáció a hagyományos japán színház

\footnotetext{
${ }^{3}$ Az ukiyo, „lebegő világ” kifejezést eredetileg buddhista összefüggésben használták, s arra utalt, hogy a földi világ örömei látszat-örömök. Az Edo-korra azonban ez a szemlélet megváltozott, a városi lakosság és az alacsonyabb rendủ szamurájok által kedvelt mindennapi szórakozások kifejezése lett. Az ezeket megjelenítő képeket hívják ukiyo-ének. Fő témájuk eleinte a szép hölgyek (gésák és kurtizánok is) illetve híres kabuki jelenetek és színészek ábrázolása volt. A későbbiekben jelentek meg a város- és tájképek. Kiemelkedő alkotók voltak Katsushika Hokusai 葛飾北斎 (1760-1849) (A Fuji harminchat látképe) és Utagawa Hiroshige 歌川 広重 (1797-1858) (A keleti-tengeri út - a Tōkaidō ötvenhárom postaállomása) (Mecsi, 2009. 146. o.).
}

fö műfajait, vagyis a nót és a kabukit is érintette, s elmondható, hogy egyik forma sem tudott reagálni a „hirtelen jött” változásokra. A 14-15. század folyamán kialakult nó már a kabuki 17. századi születésekor is rögzült szabályrendszerrel rendelkezett, s összetettségét, kifinomultságát csak a legműveltebbek tudták élvezni. Ulysses S. Grant4 Japánban tett látogatása után maga mondta, hogy ezt a müfajt meg kell örizni: „Egy ilyen nemes és gyönyörű művészet könnyen értéktelenné válhat és az idő változó ízlése lerombolhatja. [Ezért önöknek] erőfeszítéseket kell tenniük a megőrzéséért." (Keene, 1973. 44. o.) S egy, a nyugati hatalmat reprezentáló személytől tett ilyenfajta elismerő kijelentés megerősítette a japánokat abban, hogy a nó az ország jelképe, melynek ezáltal esélye sem volt a változásra.

A nyugati hatások egyre erősödő tükrében a kabuki szintén egyfajta nosztalgikus érzést váltott ki az emberekben a Tokugawa-évek (1603-1868) után, de ennek a müfajnak a „megmerevedése” ellen jelentős küzdelem indult mind kormányzati, mind színészi oldalról (Doma, 2018).

Az országnyitás a nyugati kultúra beáramlása mellett természetesen lehetővé tette, hogy a japánok is nagy számban elhagyják az országot, s megismerkedjenek más - amerikai és európai - országok szokásaival. Nem volt ez másképp a sorra alakuló színtársulatok esetében sem, akik egyrészt az új színházi tapasztalatok megszerzése, a nyugati, modern dráma és előadóművészet tanulmányozása érdekében, másrészt a hagyományos japán színházi műfajok bemutatása miatt hagyták el hazájukat. A korszak számos utazótársulata számára kiváló fellépési lehetőséget biztosítottak a népszerü gyarmati és világkiállítások, ahol - kapcsolódva a „keleti láz”-hoz - fokozni tudták a közönség egzotikum iránti lelkesedését. Fontos azonban megjegyezni, hogy bár a korabeli beszámolók a legtöbb

4 Ulysses S. Grant (1822-1885), az Amerikai Egyesült Államok 18. elnöke (hivatali idő: 1869-1877), aki volt elnökként 1879-ben világkörüli útja során Japánban is járt, ahol egy kabuki- és egy nóelőadáson is részt vett. 
esetben a különböző országok - így például Japán - autentikus produkcióinak bemutatásáról szólnak, ezek az előadások általában már a nyugati ízléshez és elvárásokhoz igazodtak.

\section{A Kawakami-társulat és Sadayakko}

Hasonló módon járta végig az Egyesült Államokat és Európát Kawakami Otojirō 川上 音二郎 (1864-1911) és társulata is 1899 és 1902 között. Kawakami a shinpa 新派, vagyis az új iskola egyik alapító atyja, mely müfaj a kabukival mint a régi iskolával szemben definiálta magát, s az egyik első reakciónak tekinthető a nyugati dráma megjelenését követően. Az amatőrökből és diákokból szerveződő új színi társulatok koruk valóságát kívánták színpadra állítani, az aktuális társadalmi problémákra reflektálni. Legnagyobb úításaik közé tartozott a női szerepek színpadon való megjelenítése nők által, vagyis a szerepek és a színészek biológiai nemének megfeleltetése. Emellett számos más, modernnek és újítónak számító színházi szokást is bevezettek, többek között a nézőtér elsötétítését, a darabok témáját tekintve pedig az előadások társadalmi, politikai színezetet kaptak. Leggyakrabban különböző újságok cikkeit vagy kortárs írók müveit vitték színre dramatizált formában, s a Meiji-korszak „családi életének romantikusan fölnagyított valóságával foglalkoztak." (Kokubu, 1984. 78. o.) Az új müfajnak - a jelentős népszerűségnek köszönhetően - sikerült a diákszínházi mozgalmat a hivatalos színjátszás színvonalára emelni és megmutatni, hogy a hagyományos színházi monopóliumon kívül is van lehetőség a létezésre. Meg kell azonban említeni, hogy a shinpaszínészek játéka néhány év elteltével valójában szinte alig tért el a hivatásos kabukiszínészekétől, s emellett realisztikusnak sem volt mondható (Ortolani, 1995. 233. o.). A műfaj jelentősége abban áll, hogy megteremtette a feltételeket a nyugati értelemben vett modern dráma és színház megjelenéséhez Japánban. Kawakami Otojirō pedig a nyugati ízléshez és dramaturgiához alakított shinpa- és kabukielőadásainak átirataival járta a nyugati országokat, ahol fóként feleségének, Sadayakkónak köszönhetően jelentős sikereket értek el.

Kawakami Sadayakkót 川上貞奴 (18711946) a japán színháztörténet az ország egyik első színésznőjeként tartja számon, aki tevékenységével hozzájárult a női színjátszás elfogadásához és a következő színésznő-generáció kineveléséhez. Sadayakko gésaként kezdte pályafutását, majd Kawakami feleségeként elkísérte férjét nyugati körútjára, ahol ő is fellépett kisebb szerepekben. A társulat azonban ráébredt, hogy az amerikai közönségnek szüksége van arra, hogy a női szerepeket nők testesítsék meg, így hamarosan férje összes átalakított, „nyugatiasított” előadásának a föszereplöjévé vált, s különböző táncaival és főként $A$ gésa és a lovag című előadásban bemutatott haláljelenetével aratott sikert az európai közönség előtt az 1900-as párizsi világkiállításon. Ennek hatására a Kawakami-társulat 1901 és 1902 között a híres táncosnő, Loïe Fuller támogatása mellett egész Európát bejárta, s szinte minden nagyobb városban fellépett, ahol a közönség úgy tekintett Sadayakkóra, mint a japán Sarah Bernhardt-ra.

A társulat 1902-ben, Japánba való viszszatérése után célul tủzte ki, hogy a nyugati útjaik során tapasztalt élményeiket a hazai közönségnek is megmutassa, s megismertetik őket a nyugati színjátszással. İgy a Kawakamitársulat nevéhez kötődik többek között a Shakespeare-színjátszás kultuszának kialakítása és meghonosítása a szigetországban. A nyugati drámák színpadra állításához azonban elengedhetetlen feltételnek bizonyult a nők színpadi szerepeltetése, amellyel már a shinpa is kísérletezett, ám ezen „újítás” elfogadása és állandóvá tétele nem volt könnyü feladat.

\section{A nők színpadon való megjelenése és oktatása}

A sógunátus ugyan a kabuki táncosnők prostituálódása miatt 1629-ben betiltotta a nők színpadon való bárminemű megjelenését, s ez a törvény egészen 1877-ig érvényben volt, ennek ellenére léteztek női előadók ebben az időszakban is, csupán tevékenységüket zárt 
Japán első színésznőképzője

vagy elszigetelt környezetben végezték. Ebbe a kategóriába tartoztak egyrészt a gésák által bemutatott színpadi táncok, melyeket teaházakban vagy a gésanegyedekben tartott különböző fesztiválok alkalmával, vagyis elszeparált és nem mindenki által látogatható helyeken mutattak be, másrészt meg kell említeni a női kabukijátszást, mely már a Meijimegújulás előtt is létezett. Az okyōgenshinek お狂言師 nevezett nők kizárólag női közönség előtt, szintén zárt helyeken, például a sógun vagy az egyes daimyōk rezidenciájának női lakrészében mutatták be előadásaikat. Ezek az alkalmak biztosítottak lehetőséget a női tánctanárok képzésére és a kultúrakedvelő szamuráj- és kereskedőcsaládok hölgytagjainak szórakoztatására. A Meiji-megújulást követően félhivatalosan működő női társulatok alakultak az okyōgenshikből, akik a másod- és harmadosztályú férfi kabuki versenytársaivá tudtak válni, és különböző tokiói kereskedelmi színházakban léptek fel. Ebben az időszakban már onna yakushaként 女役 者, vagyis női előadóként emlegették őket, előadásaik pedig onna shibai 女芝居, női darabok vagy musume kabuki 娘歌舞伎, azaz lány kabuki néven futottak ${ }^{5}$. A férfiakat és nőket egyaránt foglalkoztató vegyes társulatok tilalmát azonban csak pár évvel később, 1891ben oldották fel, s ezt követően jelentek meg először a férfiak mellett nők is a shinpa színpadán. Úttörő volt a gésa előélettel rendelkező Chitose Beiha 千歳米坡 (1855-1913), aki 37 évesen a törvény feloldását követően először állt színpadra a Seibikan társulat tagjaként az Egy hölgy erkölcsössége: a politikai pártok gyönyörü története (政党美談淑女之 操 Seitōbidan shukujo no misao) című előadásban (Rimer, Mori és Poulton, 2014. 6. o.). Ennek ellenére a japán színház-történet-írás mégsem őt, hanem Sadayakkót tekinti az ország első színésznőjének.

\footnotetext{
${ }^{5}$ A műfaj kiemelkedő képviselője volt Ichikawa Kumehachi 市川九女八 (1846?-1913), aki az első női tanítványa volt IX. Ichikawa Danjūrōnak. Tehetsége volt a férfi szerepek eljátszásához, és kiválóan imitálta a kortárs kabuki sztárokat is. 1893-ban saját női társulatot alapított (Edelson, 2008. 69-98. о.).
}

Látható tehát, hogy az 1800-as évek végén igen kevés olyan nő volt Japánban, aki kellő színházi gyakorlattal rendelkezett volna. A legtöbben csakúgy, mint Chitose Beiha, vagy épp Sadayakko, gésaként kezdte pályafutását, s a fiatal korukban elsajátított művészi képzés segítette őket a színpadon. Ez azonban nem volt elegendö, s az egyre kifinomultabbá való shinpaelőadásokhoz már magasabb szintű kvalitásokra volt szükség, így felmerült az igény a színésznőképzés hiánypótlására.

Sadayakko - mivel Párizsban tanúja volt, hogy a társadalom támogatásával hogyan nevelik ki a franciák a következő generációk nagy színésznőit - utolsó európai útjáról visszatérve döntött az iskolaalapítás mellett, s ezzel az egyik legnagyobb hatást gyakorolta a japán színháztörténetre. Álmát beteljesítve 1908-ban megnyitotta a Birodalmi Színésznőképző Intézményt (Teikoku Joyū Yōseijo 帝国女優養成所), Japán első színésziskoláját nők számára, ahol már fiatal koruktól kiválogatták és nevelték a hivatásos színésznőket. Erről az eseményről még egy magyar hetilap, az Új Idők is beszámolt, s jelentős eseményként írt az iskolaalapításról: „Ez a kis szini iskola, amelynek ma tizenöt női növendéke van, a japán színészet reformjának jelentős lépése. A ferdeszemü, sárga arcú nipon-ok kezdetben meglehetős tartózkodással fogadták Kavakami és Sada Yakko új vállalkozását, de azután rövidesen megértették e lépés jelentőségét, amely új és modern színésznőket akar adni Japánnak és amint ezt Sada Yakko pályafutása mutatja, az egész világnak, hogy azután újabb dicsőséget szerezzenek a japánoknak a világot jelentő deszkákon is, mindenütt, ahol csak a Színészetnek hívei és barátai élnek." (A japán színház, Új Idők, 1911. október 8.) Az iskola átadásán elhangzó ünnepélyes nyitóbeszédek is azt a szándékot erősítették, hogy a színésznők mind női, mind színészi mivoltukban megbecsülést váltanak majd ki, s az intézménynek köszönhetően emelkedésnek indul társadalmi megítélésük. Ennek megvalósítása azonban hosszú folyamatnak bizonyult, s számos nehézséggel, társadalmi elutasítással kellett megbirkózniuk a színésznői ambíciók- 
kal rendelkező fiatal lányoknak. Az emberek ugyanis eleinte nem tettek különbséget köztük és a gésák között, így sok megaláztatást kellett elszenvedniük. Jól példázza a közvéleményt Mori Ritsuko esete, aki felsőbb társadalmi réteg tagjaként jelentkezett az iskolába. Felvételének következményei közé tartozott azonban, hogy családja kiközösítette, öccse pedig öngyilkosságot követett el, mert nem akart együtt élni azzal a szégyennel, hogy nővére színésznői foglalkozást űz (Kano, 2001. 74. o.). Ebben is jól tükröződik az a feszültség, amely a nyugatnak való megfelelési kényszer és a japán erkölcsökhöz való ragaszkodás között áll fenn.

Épp ezért Sadayakko nagyon szigorú követelményeket állított a felvételiző lányok elé. Csak általános iskolai végzettséggel rendelkező, 16-22 éves fiatalok jelentkezését fogadták el, s a tanterv magába foglalta a történelem, az írás, a hagyományos és modern színjátszás elsajátításának készségeit, a japán és nyugati táncokat, továbbá az olyan hangszerek ismeretét, mint a fuvola, a váll-dob, a shamisen és a koto (Downer, 2003. 242. o.). A több száz jelentkezőből kiválasztott tizenöt lány oktatása ingyenes volt, feltéve, hogy teljesítették a kétéves képzést, majd további két évre a Kawakami-társulathoz szerződtek, illetve tanulóidejük alatt sehol nem léptek fel az intézmény falain kívül. Azok a növendékek, akik megszakították képzésüket, kötelesek voltak taníttatásuk költségeit megtéríteni és egy újság hasábjain bocsánatot kérni. Az utóbbi kikötés azokra a tanulókra is vonatkozott, „akik arra használták az intézetben elsajátított művészeteket [arts], hogy gésaként müködjenek" (Kano, 2001. 74. o.). Ebből a szabályból következtethetünk arra, hogy nem volt szokatlan, ha valaki az iskola elvégzése után gésa lett. „A színésznőnek tanulni vágyó diákok első generációja gyakran a gésanegyedekből érkezett, és egyeseknek már ez is elegendő okot szolgáltatott arra, hogy gyanúba keverjék az iskola hírnevét. A Yamato Shinbun címú újság a megnyitást követő napon »kétes erkölcsű nők gyűjtőhelye« névvel illette a Birodalmi Színésznőképző Intézményt” (Kano, 2001. 74. о.).
Noha az iskola nem gésaképzőként müködött, a tananyag egy része valóban megfelelt a maikók 舞妓, gésatanoncok oktatási menetének. Ennek ellenére a nyugati stílusú tánc, zene, színjátszás és a hagyományos kabukiképzéssel új stílust kívántak létrehozni, amelyet „színésznő-játéknak” (joyūgeki 女優 劇) neveztek. (Kano, 2001. 75. o.) Láthatjuk tehát, hogy a modern japán színház úttörő képviselői a több évszázados kirekesztettség után megkísérelték rehabilitálni a nők színjátszásban való stabil jelenlétét, hiszen az első shinpatársulatokban megjelenő színésznők helyét gyakran ismét felváltották az onnagaták 女形, a női szerepeket játszó férfi színészek.

Összefoglalva, a Birodalmi Színésznőképző Intézmény létrejötte megszilárdította és elősegítette azon realista elvárás legitimációját, mely szerint a szerepeket a színészek biológiai neme szerint kell kiosztani. Hogy ez milyen nehézségekkel járt, tökéletesen mutatja az iskola szabályzata, mely minden, az erkölcs megsértésére irányuló vádat meg kívánt előzni (épp ahhoz hasonló vádak voltak ezek, melyek miatt csaknem háromszáz évvel korábban a nőket kitiltották az eredetileg túlnyomórészt nők táncaiból álló kabukiból). Sadayakkónak tehát végső soron sikerült legalizálnia az eredeti formájában már nem létező színjátéktípus egyik legfontosabb vonását, a női színjátszást (onna-kabuki). S noha Sadayakko teljes mértékben szembe ment férje, Kawakami Otojirō elképzeléseivel, miszerint jobb, ha a zene és a tánc nem keveredik bele az előadásokba, az oktatás elsősorban éppen azokra a látványosságokra támaszkodott, melyek a nyugati közönséget lenyügözték és Sadayakkót híressé tették, s éppen ez a fajta - romantikát, zenét, táncot és más erős hatásmechanizmusokat használó - játékmód vált népszerűvé a japánok körében is, köszönhetően a színésznők képzésének. Elmondható tehát, hogy az iskola több éves fennállása az, amely intézményi szinten elsőként erősítette meg a női színjátszás létjogosultságát, s ezzel jelentősen elősegítette a modern színjátszás meghonosodását Japánban. 
Japán első színésznőképzője

\section{Felhasznált irodalom}

Doma Petra (2018): A hagyományos kabuki és a shinpa háborúja a XIX-XX. század fordulóján, Távol-keleti Tanulmányok, 9. 2. sz., 133-150.

Downer, L. (2003): Madame Sadayakko. Review, Polmont.

Edelson, L. (2008): The Female Danjūrō: Revisiting the Acting Career of Ichikawa Kumehachi, The Journal of Japanese Studies, 34. 1. sz., 69-98. https://doi.org/10.1353/jjs.2008.0022

Itō Nobuo, Maeda Taiji, Miyagawa Torao és Yoshizawa Chū (1980, szerk.): Japán müvészet. Budapest, Corvin Kiadó.

Janó István (2009): A Nyugat és Japán közötti kulturális kölcsönhatások rövid története. In: Farkas Ildikó (szerk.): Ismerjük meg Japánt! Bevezetés a japanisztika alapjaiba. Budapest, ELTE Eötvös Kiadó. 149-170.

Keene, D. (1973): No - The Classical Theatre of Japan. Tokyo, Kodansha.
Kokubu Tamocu (1984): A japán színház. Budapest, Gondolat.

Mecsi Beatrix (2009): Rövid bevezető a japán müvészet történetébe. In: Farkas Ildikó (szerk.): Ismerjük meg Japánt! - Bevezetés a japanisztika alapjaiba. Budapest, ELTE Eötvös Kiadó. 137-148.

Ortolani, B. (1995): The Japanese Theatre: From Shamanistic Ritual to Contemporary Pluralism. Princeton, Princeton University Press.

Rimer, J. Thomas, Mori Mitsuya \& Poulton, M. Cody (2014, szerk.): The Columbia Anthology of Modern Japanese Drama. Columbia, Columbia University Press. https://doi.org/10.7312/rime12830

Takó Ferenc (2018): Fordítva. Nyugati társadalomfilozófiai koncepciók és terminusok „japanizációja” a korai Meiji érában. Távolkeleti Tanulmányok, 9. 2. sz., 151-187.

\section{Japan's first acting school for women}

The Meiji Restoration in 1868 brought about momentous changes in Japan. Western culture, including the new and more modern Western theatre, reached the Japanese people. This represented a fundamental challenge for traditional Japanese theatre, especially for the kabuki. Besides the radical reform plans, the issue of women appearing on stage was highly debatable because of the official ban introduced in 1629 which prohibited women from performing in any theatre. On the other hand, after the Restoration, the new, Westernised genres like shinpa and shingeki used actresses in performances. There are questions about where these actresses came from and what kind of training they received. Sadayakko Kawakami, who is considered the first Japanese actress and who toured the United States and Europe with her husband, Otojiro Kawakami at the turn of the 19th and 20th centuries, established the Teikoku Joyū Yöseijo, the first Japanese acting school for women, in 1908. In this institution, based on French models, only young girls were trained.

Keywords: Japanese theatre, actress, Sadayakko Kawakami, actress training school, education

Doma Petra (2019): Japán első színésznőképzője. Gyermeknevelés, 7. 1. sz., 30-35. 